\title{
Analisis Sentimen Haramnya Musik Secara Umum Menggunakan Metode KNN
}

\author{
Rahmad Saudi Al Fathir', Thami Rusdi Agus², Ayu Adelina Suyono ${ }^{3}$, Fardiansyah Ibrahim ${ }^{4}$ \\ ${ }^{1,2,3,4}$ Universitas Amikom Yogyakarta \\ *rahmatsaudi@students.amikom.ac.id
}

\begin{abstract}
This study discusses the application of the K-Nearest Network algorithm in the case of sentiment analysis. Sentiment analysis was carried out on comments in videos discussing the prohibition of music. The data source was taken from the lecture of Ustadz Dr. Syafiq Riza Basalamah, M.A. The titles of video are Hukum Musik dalam Islam Beserta Dalilnya, Hukum Musik dalam Islam LENGKAP: Musik HALAL atau HARAM, dan Hadits Haramnya Musik Dhaif. The comments data used are 2114 in Bahasa Indonesia. Comments are divided into 3 classes, including Accept, Not Accept, and Confused. The test results show a relatively low accuracy value, which is at the level of 65\%. This is due to the lack of data included in the test.
\end{abstract}

Keywords: sentiment analysis, knn, YouTube, comments, music

\begin{abstract}
Abstrak
Penelitian ini membahas tentang penerapan algoritma K-Nearest Network dalam kasus analisis sentimen. Analisis sentimen dilakukan terhadap komentar dalam video yang membahas tentang haramnya musik. Sumber data diambil dari ceramah Ustadz Dr. Syafiq Riza Basalamah, M.A. dengan judul Hukum Musik dalam Islam Beserta Dalilnya, Hukum Musik dalam Islam LENGKAP: Musik HALAL atau HARAM, dan Hadits Haramnya Musik Dhaif. Data komentar yang digunakan sejumlah 2114 data berbahasa Indonesia. Komentar dibagi menjadi 3 kelas, diantaranya Menerima, Tidak Menerima, dan Bingung. Hasil pengujian menunjukkan nilai akurasi yang relatif rendah, yaitu pada tingkat $65 \%$. Hal ini diakibatkan karena kurangnya jumlah data yang disertakan dalam pengujian.
\end{abstract}

Kata kunci: analisis sentimen, knn, YouTube, komentar, musik

\section{Pendahuluan}

Text mining merupakan sebuah teknik yang dapat mengambil pengetahuan dari data yang berupa teks. Dalam text mining, terdapat suatu cabang ilmu yang dinamakan analisis sentimen. Analisis sentimen dilakukan untuk mengelompokkan teks yang berasal dari sentimen, apakah termasuk kategori positif, negatif, atau netral. Manusia mulai menggunakan teknik ini untuk menilai bahasa yang digunakan oleh manusia lainnya sebagai bahan dari pengetahuan. Analisis sentimen dapat dilakukan dengan mengambil data yang berasal dari ulasan, komentar, tweet, dan sebagainya.

Dalam penelitian ini, peneliti akan melakukan analisis sentimen berdasarkan komentar yang terdapat dalam video
YouTube yang bersumber dari ceramah Ustadz Dr. Syafiq Riza Basalamah [1]-[3]. Dalam akun YouTube Yufid.TV - Pengajian dan Ceramah Islam. Ceramah tersebut membahas secara lengkap mengenai halal atau haramkah musik dalam agama Islam.

Menurut KBBI, musik merupakan nada atau suara yang disusun sehingga menghasilkan irama dan lagu [4]. Musik sudah menjadi bagian dalam kehidupan sehari-hari. Dari zaman dahulu hingga sekarang, masyarakat telah mengenal dan menikmati musik. Namun dalam lingkup agama terutama Islam, halal atau haramkah musik? Pertanyaan ini tentu sering terpikirkan dalam benak setiap umat muslim, baik di Indonesia maupun seluruh dunia. 
Terdapat beberapa penelitian yang dilakukan sebelumnya dalam analisis sentimen. Analisis tersebut mengambil data yang bersumber dari ulasan, komentar, maupun tweet. Seluruh penelitian yang dipaparkan menggunakan KNN sebagai metode klasifikasinya. Penelitian pertama dilakukan dengan memanfaatkan sumber data berupa tweet dalam media sosial Twitter. Dalam penelitian yang dilakukan oleh [5]-[9] memiliki hasil yang berbeda dalam tiap tingkat akurasinya. Penelitian yang dilakukan oleh Deviyanto dalam kasus analisis sentimen tentang topik Pilkada DKI, nilai hasil akurasi terbesar hanya mencapai $67,2 \%$ [8]. Sedangkan dalam penelitian yang dilakukan oleh [5]-[7], [10] memiliki performa KNN yang memuaskan dalam tingkat $80 \%$, $95,58 \%, 96,36 \%$, dan $87 \%$. Terdapat pula penelitian yang dilakukan dengan memanfaatkan data yang berasal dari komentar atau ulasan. Penelitian tersebut dilakukan oleh [10], [11]. Penelitian ini menghasilkan tingkat akurasi sebesar 77,01\% dan $87 \%$. Hasil penelitian tersebut dapat dijadikan sebagai bukti bahwa metode KNN dapat dimanfaatkan dengan baik untuk melakukan klasifikasi pada analisis sentimen.

Berdasarkan penjelasan yang telah dipaparkan, maka dalam penelitian ini akan dilakukan analisis berdasarkan komentar yang terdapat dalam video YouTube yang bersumber dari [1]-[3] menggunakan Algoritma KNN. Komentar yang menjadi sumber data akan dikelompokkan menjadi 3 kelas, yaitu Menerima, Tidak Menerima, dan Bingung. Hasil dari analisis sentimen ini dapat digunakan sebagai dasar pengetahuan apakah penonton video tersebut sudah memahami konten dari video ataukah belum. Sehingga pemilik konten maupun penyampai materi dapat melakukan tindakan selanjutnya demi konten yang lebih baik di masa depan.

\section{Metoda Penelitian}

\subsection{Text Mining}

Text mining didefinisikan sebagai sebuah teknik yang menggunakan data berupa teks. Text mining digunakan untuk menggali pengetahuan dalam sekumpulan teks [12]. Secara umum text mining memiliki 3 tahap utama, yakni text processing, feature selection, dan text analytic. Text processing merupakan tahap yang dilakukan untuk mempersiapkan data. Dalam penelitian ini text processing dilakukan dengan tahapan cleaning, tekonizing, stemming, dan stop removal. Setelah tahap text processing, dilanjutkan dengan feature selection. Pada tahap ini akan ditentukan kata kunci dari suatu corpus. Dalam penelitian ini feature selection dilakukan dengan pendekatan TF-IDF. Term Frequency/Inverse Document Frequency (TF-IDF) merupakan gabungan dari pendekatan TF dan IDF yang perhitungannya diambil dari rasio nilai TF dan IDF [12]. Tahap akhir merupakan text analytic menggunakan analisis sentimen. Penjelasan lebih lanjut mengenai analisis sentimen akan dibahas pada sub bab 2.2.

\subsection{Analisis Sentimen}

Analisis sentimen merupakan suatu proses yang digunakan untuk menentukan sentimen untuk mengelompokkan teks dalam beberapa kategori, yaitu positif, negatif, atau netral [9]. Proses analisis dapat dilakukan ulasan, komentar, tweet, dan sebagainya.

\subsection{K-Nearest Network}

KKN merupakan salah satu metode yang digunakan untuk klasifikasi. Algoritma ini melakukan klasifikasi berdasarkan data training yang memiliki jarak paling dekat dengan obyek k [13]. Metode ini dikenal memiliki cara kerja yang sederhana dibandingkan dengan algoritma yang lainnya. Persamaan matematis Algoritma KNN ditunjukaan dalam Persamaan 1 [14].

$$
\operatorname{similarity}(T, S)=\frac{\sum_{i=1}^{n} \quad f\left(T_{i}, S_{i}\right) * W_{i}}{W_{i}}
$$

\subsection{Perancangan Penelitian}

Langkah penelitian yang dilakukan dalam penelitian ini antara lain:

1. Pengumpulan Dataset

Pengumpulan data dilakukan dengan mengambil data dari komentar YouTube. Data diambil kemudian dikelompokkan menjadi 3 kelas.

2. Pengolahan Awal Data

Pengolahan data diawali dengan processing data, seperti cleaning, tokenizing, stopwords, stemming. 
Setelah processing data selesai dilakukan, dilanjutkan dengan proses frequency distribution dan classification.

3. Evaluasi dan Validasi Hasil

Setelah ditemukan hasilnya, maka dilakukan proses pengujian sehingga dihasilkan akurasi dari pengujian tersebut.

\section{Hasil Penelitian}

\subsection{Pengumpulan Dataset}

Pada penelitian ini dikumpulkan sebanyak 2114 data komentar berbahasa Indonesia yang berasal dari video YouTube mengenai haramnya musik dalam islam. Komentar dalam penelitian ini dikelompokkan dalam 3 (tiga) kelas, yakni Menerima, Tidak Menerima, dan Bingung.

Berikut contoh komentar Menerima, Tidak Menerima, dan Bingung:

1. Komentar Menerima

Contoh komentar menerima:

Assalamualaikum... afwan ana mau membalas komentar antum, sebelum.a ana juga masih awam mslah agama.... tp disini ana cuma mau sharing... Inpertama tanya dulu diri antum mau menerima sunnah Rasul salallahu alaihi wasallam ga??? klo ga mau sa susah tp klo mau Alhamdulillah... vndan untuk meluruskan, ust.Syafiq itu tidak terpojokan sekali lagi tidak terpojokan. antum dengerin yg beliau sebutkan itu hadits shahih dan memang begitu hukum.a musikpun di halalkan di acara khusus seperti berbohong yg haram tp dibolehkan dalam hal hal tertentu.. itupun alat musik. a cuma rebana yg murni tanpa suara lain seperti afwan di daerah ana itu kecrek yg biasa ada di pinggiran rebana/duf..... Wbarakallahu fiik... klo kurang jelas boleh antum jawab lg.

2. Komentar Tidak Menerima

Contoh komentar tidak menerima:

bagi AKU NYINDIR DAN Buka aib orang itu di youtube itu HALAL!!!!!! hei pak ustad ceramah sono di masjid ceramah di youtube!!! ceramah kok pake bahasa planet!!! gak ngerti diriku!!!
3. Komentar Bingung

Contoh komentar bingung:

rasul memperbolehkan rebana ya karena memang sudah budaya bangsa arab pada masa itu menjadikan rebana sebagai alat musik lokal mereka, beda dengan indonesia alat musik lokal nya beranekaragam, ada gendang, kecapi, angklung, tanjidor, gamelan, kecapi, sasando, dll. jadi tak ada masalah memainkan alat musik lokal di pernikahan atau hari raya.

\subsection{Pengolahan Data Awal}

Tahapan proses dalam pengolahan data, antara lain:

\section{Cleaning}

Proses cleaning digunakan untuk membersihkan kata maupun karakter yang tidak diperlukan, sehingga data berisi kata yang diperlukan saja. Hasil cleaning dapat dilihat pada Tabel 1 .

Tabel 1. Proses Cleaning Data

\begin{tabular}{cc}
\hline Contoh Teks & Contoh Teks \\
$\begin{array}{c}\text { Sebelum Proses } \\
\text { Cleaning }\end{array}$ & $\begin{array}{c}\text { Setelah Proses } \\
\text { Cleaning }\end{array}$ \\
\hline Musik tidak haram & Musik tidak haram \\
Yang haram orang & Yang haram orang \\
menggunakan... & menggunakan... \\
\hline
\end{tabular}

2. Tokenizing

Proses tokenizing dilakukan untuk memisahkan kalimat menjadi kata tunggal. Hasil tokenizing dapat dilihat pada Tabel 2.

Tabel 2. Proses Tokenizing Data

\begin{tabular}{cc}
\hline Contoh Teks & Contoh Teks \\
$\begin{array}{c}\text { Sebelum Proses } \\
\text { Tokenizing }\end{array}$ & $\begin{array}{c}\text { Setelah Proses } \\
\text { Tokenizing }\end{array}$ \\
\hline Musik tidak haram & [musik, tidak, haram, \\
Yang haram orang & yang, haram, orang, \\
menggunakan... & menggunakan... \\
\hline
\end{tabular}

3. Stopwords

Proses ini dilakukan untuk menghilangkan kata-kata yang tidak memiliki arti, seperti ada, adalah, adanya, adapun, dan sebagainya. Selain itu pada proses ini juga diberikan fungsi untuk memberikan penjelasan kepada kata-kata yang merupakan inisial atau singkatan, seperti 'yg' menjadi 'yang', 'bc' menjadi 
'baca', 'bs' menjadi 'bisa', dan sebagainya.

\section{Stemming}

Proses ini dilakukan untuk memisahkan kata dasar dengan kata imbuhannya. Karena teks yang digunakan merupakan teks berbahasa Indonesia, maka library yang digunakan adalah library Sastrawi. Hasil stemming dapat dilihat pada Tabel 3.

Tabel 3. Proses Stemming Data

Contoh Teks Setelah Proses Stemming

0[ustaz, musik, ajar, cerdas, manusia, ajar, se... 1 [musik, haram, haram, orang, musik, lalai...

2[ustaz, safiq, baca, riwayat, musik, musik...

3 [musik, dapat, allah, rasul, orang, pilih, iku...

4 [seruling, soneta, grup, pimpin, bang, haji, r...

Setelah processing data selesai dilakukan dilanjutkan dengan proses frequency distribution. Proses ini dilakukan untuk mengetahui sebanyak apa kata disebut dalam seluruh data. Hasil frequency distribution dapat dilihat pada Tabel 4 .

Tabel 4. Proses Frequency Distribution

\begin{tabular}{cc}
\hline Token & Frekuensi \\
musik & 2164 \\
haram & 1088 \\
allah & 496 \\
orang & 414 \\
\hline
\end{tabular}

Setelah frequency data dilakukan, proses dilanjutkan dengan proses klasifikasi komentar menggunakan algoritma KNN. Hasil pengujian menggunakan algoritma KNN ditunjukkan pada Gambar 1.

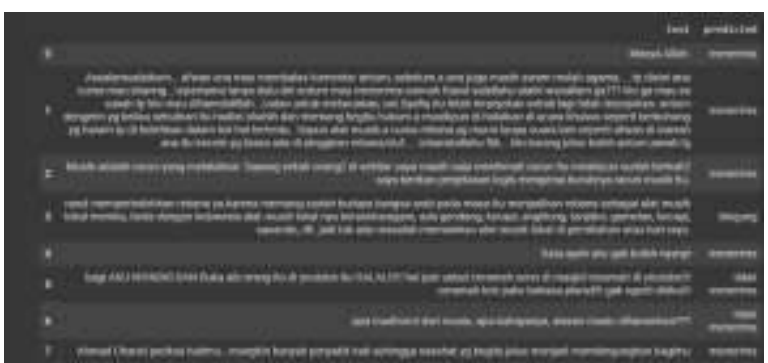

Gambar 1. Hasil Pengujian menggunakan Algoritma KNN

\section{Kesimpulan}

Berdasarkan hasil pengujian komentar YouTube menggunakan algoritma KNN, dapat disimpulkan bahwa algoritma ini memiliki tingkat akurasi yang relatif rendah, yakni pada tingkat $65 \%$. Hal ini dapat disebabkan karena kurangnya jumlah data komentar yang dijadikan sebagai objek data.

\section{Saran}

Untuk penelitian yang lebih baik kedepannya peneliti dapat menambahkan lebih banyak data sebagai obyek data agar performa yang dihasilkan algoritma KNN dapat menjadi lebih baik dan dapat menggunakan algoritma lainnya.

\section{Daftar Pustaka}

[1] YouTube, "Hukum Musik dalam Islam LENGKAP: Musik HALAL atau HARAM? - Ustadz Dr. Syafiq Riza Basalamah, M.A.," Yufid.TV - Pengajian \& Ceramah Islam, 2014. https://www.youtube.com/watch?v=9rm3 XHfUJ_U (accessed Oct. 29, 2021).

[2] YouTube, "Hadits Haramnya Musik Dhaif? - Ustadz Syafiq Riza Basalamah," Yufid.TV - Pengajian \& Ceramah Islam, 2020.

https://www.youtube.com/watch?v=p3K YNXxppAI (accessed Oct. 29, 2021).

[3] YouTube, "Hukum Musik dalam Islam Beserta Dalilnya - Ustadz Syafiq Riza Basalamah," Yufid.TV - Pengajian \& Ceramah Islam, 2020. https://www.youtube.com/watch?v=eJEza -VNkGk (accessed Oct. 29, 2021).

[4] “KBBI Daring,” 2021. https://kbbi.kemdikbud.go.id/entri/musik (accessed Oct. 29, 2021).

[5] N. T. Romadloni, I. Santoso, and S. Budilaksono, "Perbandingan Metode Naive Bayes , Knn Dan Decision Tree Terhadap Analisis Sentimen Transportasi Krl," J. IKRA-ITH Inform., vol. 3, no. 2, pp. 1-9, 2019.

[6] R. Puspita and A. Widodo, "Perbandingan Metode KNN, Decision Tree, dan Naïve Bayes Terhadap Analisis Sentimen Pengguna Layanan BPJS," J. Inform. Univ. Pamulang, vol. 5, no. 4, p. 646, 2021, doi: 10.32493/informatika.v5i4.7622. 
[7] N. D. Mentari, M. A. Fauzi, and L. Muflikhah, "Analisis Sentimen Kurikulum 2013 Pada Sosial Media Twitter Menggunakan Metode K-Nearest Neighbor dan Feature Selection Query Expansion Ranking," J. Pengemb. Teknol. Inf. dan Ilmu Komput. Univ. Brawijaya, vol. 2, no. 8, pp. 2739-2743, 2018.

[8] A. Deviyanto and M. D. R. Wahyudi, "Penerapan Analisis Sentimen Pada Pengguna Twitter Menggunakan Metode K-Nearest Neighbor," JISKA (Jurnal Inform. Sunan Kalijaga), vol. 3, no. 1, p. 1, 2018, doi: 10.14421/jiska.2018.31-01.

[9] M. N. Ardhiansyah, R. Umar, and Sunardi, "Analisis Sentimen pada Twitter Menggunakan Metode Support Vector Machine," Semin. Nas. Teknol. Fak. Tek. Univ. Krisnadwipayana, vol. 1, no. 1, pp. 739-742, 2019, [Online]. Available: https://jurnal.teknikunkris.ac.id/index.php /semnastek2019/article/view/343/342.

[10] S. Ernawati and R. Wati, "Penerapan Algoritma K-Nearest Neighbors Pada Analisis Sentimen Review Agen Travel," J. Khatulistiwa Inform., vol. VI, no. 1, pp. 64-69, 2018, [Online]. Available: https://ejournal.bsi.ac.id/ejurnal/index.php /khatulistiwa/article/view/3802/2626.

[11] R. Sari, "Analisis Sentimen Pada Review Objek Wisata Dunia Fantasi Menggunakan Algoritma K-Nearest Neighbor (K-Nn)," EVOLUSI J. Sains dan Manaj., vol. 8, no. 1, pp. 10-17, 2020, doi: 10.31294/evolusi.v8i1.7371.

[12] R. Nugraha, Fikri Aldi., Harai, Nisa Hanum., Habibi, Analisis Sentimen Terhadap Pembatasan Sosial Menggunakan Deep Learning. Kreatif, 2020.

[13] M. Y. H. S. Raymana Aprilian, Roni Habibi, Algoritma KNN dalam memprediksi cuaca untuk menentukan tanaman yang cocok sesuai musim. Kreatif, 2020.

[14] K. S. Dasril Aldo, Afriosa Syawitri, Alwendi, Darmansah, DATA MINING. Insan Cendekia Mandiri, 2021. 